\title{
DISCRETION AND THE ECONOMICS OF DEFENSIVE BEHAVIOUR BY PUBLIC BODIES
}

\author{
Jef De $\mathrm{Mot}^{\star}$ and Michael G. Faure ${ }^{\star *}$
}

\begin{abstract}
While in many countries the liability of public authorities in negligence resembles the liability of ordinary persons quite well, several exceptions which shield public authorities from liability remain important. A policy consideration which often seems to be given weight is the risk of defensive behaviour by public officials. From a legal perspective, concerns regarding defensive behaviour are often dealt with by the rules related to discretionary decisions. We examine to what extent these rules in England, France and Germany are in accordance with the most elementary principles of the economics of defensive behaviour. We find that the rules are compliant to a considerable extent in France and Germany, and to a lesser extent in England, with the economic principles underlying defensive behaviour. Immunity is mainly granted when there is considerable uncertainty in decision-making and often is not granted when the law specifies the precise action to be taken by the public authority or when no reasonable person could come to the decision made by the public authority.
\end{abstract}

Keywords: defensive behaviour; discretion; economic analysis; immunity; public authority liability

\section{§1. INTRODUCTION}

In many countries, the liability of public authorities in negligence resembles the liability of ordinary persons quite well. However, based on explicit or implicit policy considerations, exceptions which shield public authorities from liability remain important. Some policy concerns are only relevant in some countries. For example, the argument of scarce public resources or their diversion from important public functions has had an effect on the

* University of Ghent, FWO.

** Maastricht University and Erasmus University Rotterdam. 
stance of courts in England, but not at all or much less in France and Germany. ${ }^{1}$ One policy consideration which seems to be given weight in almost all countries is the risk of defensive behaviour by public officials. ${ }^{2}$ Empirical research shows that such effects do exist in some situations. ${ }^{3}$

Theoretical research has argued that whether defensive practices arise in specific contexts depends on many factors such as the degree of uncertainty regarding the desirable behaviour, the scale of damages or reputational risk if found liable, whether there can be liability for defensive behaviour, whether public authorities are insured against liability losses and elements related to the internal organization of the public authority. ${ }^{4}$

From a legal perspective, concerns regarding defensive behaviour are often dealt with by the rules related to discretionary decisions. In this article, we examine to what extent these rules in England, France and Germany are in accordance with the most elementary principles of the economics of defensive behaviour. These rules should provide a good balance between providing incentives to take adequate care and providing disincentives to adopt a defensive attitude.

This article proceeds as follows. In the next section, we analyse defensive behaviour due to liability from an economic perspective. Section 3 discusses how the laws in England, France and Germany deal with discretionary decisions and to what extent these laws are in accordance with basic economic criteria. Section 4 offers concluding remarks.

\section{§2. THE ECONOMICS OF DEFENSIVE BEHAVIOUR}

Legal standards are fraught with uncertainty. ${ }^{5}$ This uncertainty has several sources. First, courts may err in determining due levels of care. For example, they may hold a civil servant negligent for granting a permit for an activity that later caused considerable harm, even though granting the permit was reasonable from an ex ante perspective. ${ }^{6}$ Equally, the court may mistakenly not hold a civil servant liable for granting a permit

1 See the various country reports in K. Oliphant (ed.), The Liability of Public Authorities in Comparative Perspective (Intersentia, 2016).

2 Ibid.

3 For an overview of empirical research related to defensive behaviour in the context of public authority liability and an analysis of the various factors which may influence defensive behaviour, see J. De Mot and M. Faure, 'Public Authority Liability and The Chilling Effect', 22 Tort Law Review (2014), p. 120 133.

4 Ibid.

5 See e.g. K. Oliphant, 'Against Certainty in Tort Law', in S. Pitel, J. Neyers and E. Chamberlain (eds.), Tort Law: Challenging Orthodoxy (Hart Publishing, 2013), p. 1.

6 Behavioural law and economics has shown that it is quite likely that judges will ex post hold that, with hindsight, the tortfeasor could have prevented the harm at reasonable costs, even though this may ex ante not have been clear at all. It is referred to as the hindsight bias. For a detailed discussion see J.J. 
which should not have been granted. Second, courts can make errors in assessing an injurer's factual level of care. For example, a physician may have performed a diagnostic test, ${ }^{7}$ but the court might think that he did not. On the other hand, the court may believe that the physician performed a diagnostic test when he did not. Third, a party may be unable to completely control his momentary level of duty of care. For example, a driver may not be able to control his level of duty of care at every given moment, perhaps because of a lapse of attention, a sneeze, and so forth.

In many cases, the underlying cause of uncertainty is the difficulty in determining the socially desirable level of care for either the potential injurer (ex ante) and/or the court (ex post). Police officers for example may have to decide how aggressively to intervene in a conflict. They must then balance the risks to presumed criminals against the risks to victims. Logically, there may be much disagreement in society as to the optimal aggression police officers should exercise in certain types of conflicts.

Another example concerns an administrative agency that has to make a decision to approve or not approve a particular drug: it needs to balance the potential costs of not allowing the drug (losing the positive effects of the drug and hence more illnesses which cannot be prevented) against yet another external cost (the potential danger of side effects or other negative effects resulting from the use of the drug). Such balancing is sometimes extremely difficult, and even if the agency performs this exercise with optimal care, it is still possible that a court will disagree with the decision of the agency if harm arises. With respect to England, Marsh notes that ' $[t]$ he way in which English law on the negligence liability of public bodies has evolved over the last two decades suggests that it would not be imprudent for public bodies to assume that the boundaries of negligence are rather uncertain'. 8

The magnitude of the consequences of uncertain legal standards on the behaviour of potential injurers depends on whether the potential injurer acts on his own behalf or is a public entity. We first look at the former situation. For reasons of simplicity, we will focus on the situation in which courts may err in determining due levels of care. More specifically, courts may either be too severe (holding the defendant liable, even though he did not behave negligently, this is called a 'type I-error'), or too lenient (not holding the defendant liable, even though he behaved negligently, this is called a 'type II-error'). Of course, when the type and magnitude of the court's errors are perfectly known in advance, injurers do not face any uncertainty. But often a potential injurer faces a certain probability that the court will be too severe and a certain probability that

Rachlinski, 'A Positive Psychological Theory of Judging in Hindsight', 65 The University of Chicago Law Review (1998), p. 571.

7 For example: listening carefully to a person's heartbeat after some exercises. Such a test may not be easily verifiable, unlike for example an electrocardiogram.

8 A. Marsh, 'The impact of liability on public bodies: lessons from the literature', Socio-Legal Studies Association Conference 2008, Manchester, 18-20 March 2008. 
the court will be too lenient. This introduces the element of uncertainty. ${ }^{9}$ We can easily see that the influence of type I and type II errors is quite different by looking at a simple numerical example. The first column represents the level of care a potential injurer can take. The second column represents the costs of each level of precaution (one unit of precaution costs $€ 1,000$ ). The third column represents the expected costs of an accident (the probability of an accident times the loss in case an accident happens) for each level of precaution. ${ }^{10}$

\begin{tabular}{|l|c|c|c|}
\hline Precaution level & Costs of precaution & Expected costs of accident & Total social costs \\
\hline 0 & 0 & 100,000 & 100,000 \\
\hline 1 & 1,000 & 50,000 & 51,000 \\
\hline 2 & 2,000 & 30,000 & 32,000 \\
\hline 3 & 3,000 & 25,000 & 28,000 \\
\hline 4 & 4,000 & 23,000 & 27,000 \\
\hline 5 & 5,000 & 22,500 & 27,500 \\
\hline
\end{tabular}

Clearly, the optimal level of precaution equals 4 units. The total social costs - the sum of precaution costs and expected accident costs - is smaller for 4 units $(27,000)$ than for any other level of precaution (100,000; 51,000;32,000;28,000 and 27,500 respectively). Under an error-free negligence rule, in which all judges set due care at 4 units, a potential injurer will take optimal care. If he takes less care $(0 ; 1 ; 2$ or 3 units), he does not even bear the precaution costs and the expected costs of an accident $(100,000 ; 51,000 ; 32,000$ and 28,000 respectively). In other words, he bears the total social costs. But the total social costs are lowest for 4 units (27,000), and if he takes 4 units, he doesn't even bear all the costs, but only the costs of precaution $(4,000)$. Thus he will not be inclined to take anything less than 4 units. Similarly, the potential injurer will not take more precaution than the socially optimal level of due care (he will not take 5 units). There simply is no benefit for the injurer to take more than 4 units. As soon as he takes due care ( 4 units), he will never have to pay damages. If he takes due care, his cost equates to 4,000 . If he takes an additional unit, his cost is 5,000. So taking 4 units is cheaper.

Things change however when we introduce the possibility of judicial error. We will first look at the case in which the court is too lenient, and then at the case in which the court is too strict. For reasons of mathematical simplicity, we have separated these cases

9 Note that even when there is only a probability that the court will be too severe or only a probability that the court will be too lenient, uncertainty exists. However, a combination of both possibilities seems most realistic.

10 We have of course made up the numbers in this example. However, they are realistic in the sense that we assume that more investments in precaution (hence increasing precaution costs) reduce the expected accident costs, but that the marginal return on those investments is decreasing. This is a standard assumption in the economic analysis of accident law. See for example S. Shavell, 'Strict Liability versus Negligence', 9 Journal of Legal Studies (1980), p. 1-25. 
and assume that the potential injurer knows the type and magnitude of the error in advance. In reality, as we have stated above, the potential injurer does not know with certainty which type of error will be made. Courts will make a type I error with a certain probability and a type 2 error with a certain probability. The total effect of this uncertain situation follows from combining the two results from the separate analyses. Suppose the injurer knows that judges set due care at 3 units instead of 4 . Then a potential injurer will take 3 units instead of 4 . As soon as he takes 3 units of care, he will not be held liable for any damages. His private cost is minimal when he takes 3 units of care (3,000 versus $100,000,51,000,32,000,4,000$ and 5,000 respectively). Note that the advantage for the potential injurer for this type of judicial error is 1,000: without the error, the injurer would have spend 4 units of care (cost of 4,000), with the error he only spends 3 units (cost of 3,000).

We now look at the other type of error. Suppose the potential injurer knows that judges set due care at 5 units. Then he will effectively take 5 units of care. For any lower number of units, the injurer will bear all the costs $(100,000,51,000,28,000,27,000)$. If he takes 5 units, he only bears the costs of precaution $(5,000)$. Note that the advantage of taking too much care is quite large $(22,000)$. If the injurer only takes 4 units, he bears an expected cost of 27,000. If he takes 5 units, he pays only 5,000. So in conclusion, the effect of type I and type II errors is different. Even when both types of errors are equally likely from an ex ante perspective (for example there us a 10\% chance for a type I error and a $10 \%$ chance for a type II error), potential injurers will be more inclined to take too much care than too little care.

We now argue that this problem of over-precaution (defensive practices) is much more serious where a public authority is involved. A private tortfeasor typically balances an external cost (the expected accident cost) against an internal cost (his precaution cost). The incentive of such a tortfeasor to take too much precaution is limited, since he has to pay all the costs of over-precaution himself.

However, public authority officials typically balance two external costs. ${ }^{11}$ Unlike the private tortfeasor, the public authority itself does not bear the costs of over-precaution. The public authority is thus much more inclined towards taking too much precaution, because others are bearing the costs of it. For example, firefighters balance damage caused by water (due to an intervention) against damage caused by fire (the costs of inaction). Both of these costs are externalized. Similarly, a safety inspector balances the expected costs of accidents against the costs of taking precautions. The former are borne by the victims (in case of an accident), the latter by the inspected firm (for example as additional safety measures). ${ }^{12}$ Briefly summarized, the combination of the uncertainty

11 This point is stressed in G. De Geest, 'Who should be immune from tort liability?', 41 Journal of Legal Studies (2012), p. 291.

12 As De Geest argues, these injurers are in a multitasking agent situation. The multitasking agent literature shows that incentives usually need to be softer for these agents than for single-task agents, because hard incentives for one output can distort the incentives for the other output. For example, 
of legal standards and the possibility of the government to externalize the costs of overprecaution may lead to strongly defensive behaviour.

We stress that chilling behaviour is less likely when public authorities can be held liable for their defensive behaviour. ${ }^{13}$ Public authorities can sometimes be held liable for acting too cautiously. If a public authority for example declines to grant a permit because it fears that the activities of the company asking for the permit may cause harm for which the authority could be held liable, and the courts determine ex post that it should have granted the permit, then the government may be held liable and be forced to compensate the lost profits. Public authorities thus need to balance the potential liability costs of being too lenient with the potential liability costs of being too strict.

Several particularities of a legal system may influence this balancing undertaken by the public authority. Not all legal systems impose liability for pure omissions: ${ }^{14}$ for instance, there is no general duty of care in tort to prevent harm occurring to another in the common law. ${ }^{15}$ The normal mechanism for creating affirmative duties of action is contract or statute. Due to the nonfeasance doctrine, public authorities can pull out from providing certain services without the fear of liability. This may substantially enhance the scope for chilling effects. Another example concerns the rules on pure economic loss. In some jurisdictions, when the courts are faced with a loss which does not stem from any physical damage to the claimant or her property, this loss is not recoverable in the tort of negligence. ${ }^{16}$ In some cases, this can lead to chilling behaviour. Suppose that a public authority must decide on granting a permit to a firm for a dangerous activity which may mainly cause physical damage, ${ }^{17}$ and that not granting the permit leads to pure economic losses. Then the public authority may be more likely to refuse a permit when pure economic losses are not recoverable. By not granting a permit, it can escape liability costs in case the activity causes physical harm and the court concludes that the authority was too lenient when granting the permit, without having to be concerned about potential liability payments in case a court would be in the opinion that the permit should have been granted.

professors who are paid per publication may neglect their teaching efforts, when these teaching efforts are hard to verify (and thus to sanction). In the context of liability, multitask agents should be allowed to exercise discretion within a well-defined zone with clear minimum constraints. The reason is that uncertainty has a strong chilling effect in a multitasking agent situation, because the multitasking agent does not internalize the precaution costs. For example, if a public servant needs to decide whether a firm should get a permit or not to carry out a risky activity that can cause substantial harm to third parties. See G. De Geest, 41 Journal of Legal Studies (2012). This is an important difference with private actors. If these take too much care due to uncertain legal standards, the usual consequence for them is that their private costs of prevention increase. In other words, whether there is liability not only for misfeasance, but also for nonfeasance. Smith v. Littlewood Organisations Ltd [1987] 2 AC 241.

On pure economic loss in Europe, see M. Bussani and V. Palmer (eds.), Pure Economic Loss in Europe (Cambridge University Press, 2003).

And there is a probability that the authority will be held liable for the losses. 
To keep the numerical example as simple as possible, we have assumed that there is one single actor who bears the consequences of a liability verdict. In reality, things are more complex. Often the individual civil servant cannot be held personally liable, except for gross negligence or intent, but the agency can be held liable. Furthermore, sometimes a public authority has a right of recourse against its civil servant, but this right is not always used. However, also under these circumstances, chilling effects can arise. First, other consequences apart from the payment of damages can be attached to a liability verdict (and the prospect of it) and these may have strong incentivizing effects as well. A civil servant who committed a fault may face disciplinary sanctions (such as dismissal). In addition, non-financial costs - such as loss of time, stress, and especially damage to reputation - are also important. From the point of view of the individual civil servant, engaging in defensive behaviour can also limit these kind of costs. With respect to reputational loss, Epp writes

what agency officials fear most about liability is the threat of public embarrassment and reputational damage. Although losing a costly case is undoubtedly embarrassing, lawsuits have the potential to erode an agency's legitimacy in the eyes of the public even if the agency wins. As one official observed to me, 'Lawsuits bring publicity, and publicity alters the public perception of us, and for practical purposes, perception is reality. So that can be a big cost, and it can take a long time to overcome it.' ${ }^{18}$

Note that empirical research by Hartshorne et al. shows that higher level officials may not always inform lower level officials about liability verdicts that could be relevant for them in the future because this could lead to overly defensive behaviour. ${ }^{19}$ Second, when civil servants can be held liable for gross negligence, and there is uncertainty whether a type of behaviour will be regarded by the courts as not negligent, slightly negligent or grossly negligent, chilling behaviour may once again arise.

\section{§3. THE LAW}

Theoretical and empirical analysis shows that defensive behaviour can materialize under certain circumstances. Consequently the question arises as to how the law can prevent such behaviour or at least reduce its occurrence. Given that uncertainty (whether the correct standard will be applied by the courts) is at the heart of defensive behaviour, the most straightforward remedy is to provide more certainty. Of course, policymakers could try to formulate laws as precisely as possible, but obviously there is a limit to that. No matter how clearly rules are formulated, there will always be some residual

18 C. Epp, Making Rights Real: Activists, Bureaucrats, and the Creation of the Legalistic State (University of Chicago Press, 2009), p. 22.

19 See J. Hartshorne, N. Smith and R. Everton, 'Caparo under fire: a study of the effects upon the Fire Service of liability in negligence', 63 Modern Law Review (2006), p. 502-522. 
uncertainty. ${ }^{20}$ Additional certainty can be provided by granting immunity for decisions which are inherently surrounded by substantial uncertainty. Naturally, this immunity should not go further than necessary. First, when the law specifies the precise actions the public authority must take, there is no uncertainty and no need for immunity. Second, even when the law fails to specify the precise action that the public authority must take, granting immunity is not always desirable. When a public authority makes a policy choice that no reasonable person would ever make, there should be no immunity. This will not lead to defensive behaviour.

We will now examine whether the law in England, France and Germany is in accordance with three criteria which follow from our framework. Note that criterion 2 and 3 are corollaries of the first, most basic criterion:

1. Immunity should only be granted when there is substantial uncertainty in decisionmaking;

2. Immunity should not be granted when the law specifies the precise action to be taken by the public authority;

3. There should be no immunity if no reasonable person could come to the decision made by the public authority.

\section{A. ENGLAND}

In general, public authorities in England are subject to the same tortious liabilities as private persons. ${ }^{21}$ The most important bases of claim are negligence, breach of statutory duty and misfeasance in public office. ${ }^{22}$ A public employer is strictly liable for torts committed by its employees in the scope of their employment, but the employee may also be sued personally by the victim, and the employer has a right of indemnity against the employee ${ }^{23}$ (but this is almost never exercised). ${ }^{24}$ However, various devices have been conceived to restrict the liability for the negligence of public officials (discretion,

Note that one also has to take into account the costs of formulating clearer rules. Also, 'bright line' rules do not necessarily provide more certainty than an approach where relevant factors are identified, a weight is attached to each factor, and on that basis courts make a flexible assessment. See K. Oliphant, in S. Pitel, J. Neyers and E. Chamberlain, Tort Law: Challenging Orthodoxy, p. 1. Mersey Docks and Harbour Board Trustees v. Gibbs (1866, Law Reports (1st series) LR 1 House of Lords (HL) 93) established that public bodies have no blanket immunity from liability in tort. The Crown Proceedings Act 1947 almost completely abolished Crown immunity.

Negligence is by far the most used basis. To examine the issue of the duty of care, the three stage test developed in Caparo Industries plc v. Dickman (1990 2 AC 605, 617-618) is used. It must be reasonably foreseeable that the conduct of the defendant will cause damage to the plaintiff; there must be sufficient proximity between the parties and it must be fair, just and reasonable to impose a duty of care. Note that the last basis (misfeasance in public office) applies only to public officials. Lister v. Romford Ice and Cold Storage Co Ltd [1957] AC 555.

24 See the country report on England and Wales in K. Oliphant (ed.), The Liability of Public Authorities in Comparative Perspective (Intersentia, 2016). 
justiciability, the policy sphere), and courts are more willing to negate a duty of care for reasons of public policy when the defendant is an emanation of the state. ${ }^{25}$ It is generally acknowledged that the liability of public authorities in England is relatively restricted. ${ }^{26}$ Several liabilities that other European systems would consider typical cannot arise in England (such as the negligent refusal of a licence or permit). ${ }^{27}$

The concept of discretion is of vital significance in English case law on public authority liability. When conduct falls within the ambit of discretion conferred on the defendant by Parliament, no liability should arise. In the Dorset Yacht ${ }^{28}$ case, Lord Reid wrote 'Where Parliament confers a discretion (...) there may, and almost certainly will, be errors of judgment in exercising such a discretion and Parliament cannot have intended that members of the public should be entitled to sue in respect of such errors'. This can clearly be linked to our first economic criterion, the element of uncertainty underlying defensive behaviour. In other cases, the risk of detrimental defensive action by public officials (so-called 'overkill') is expressly mentioned as a policy consideration to be careful with public authority liability. ${ }^{29}$ Marsh notes

[if] (...) the standard of reasonableness or, more generally, the limits of liability are highly uncertain then it is not possible to identify the appropriate level of investment in harmreduction measures: this could lead those who are risk-averse to invest heavily in 'good' administrative practice to maximize their chances of meeting whatever standard will be applied, to the extent that de facto defensive administration is the result. ${ }^{30}$

Furthermore, it is acknowledged that discretion cannot be looked at in 'all-or-nothing' terms. ${ }^{31}$ The nature of discretion moves along a sliding scale. The mere existence of some element of discretion is not sufficient to rule out a duty of care. ${ }^{32}$ Referring to the first of our economic criteria, uncertainty needs to be substantial. In some situations, the optimal decision may be uncertain, but it may be quite clear that it lies in a narrow interval. Extending the scope of discretion beyond that interval will not further reduce defensive behaviour, but may give inadequate incentives to take adequate care. In Anns v. Merton $L B C,{ }^{33}$ Lord Wilberforce related the concept of discretion to the distinction K. Oliphant, 'The Liability of Public Authorities in England and Wales', in K. Oliphant (ed.), The Liability of Public Authorities in Comparative Perspective.

See e.g. C. Van Dam, European Tort Law (Oxford University Press, 2006), p. 473.

See Jain v. Trent Strategic Health Authority (2009) UKHL 4, (2009) AC 853. (1970) AC 1004, 1031.

See e.g. Rowling v. Takaro Properties Ltd (1988) AC 473, 502 per Lord Keith (Privy Council); Hill v. Chief Constable of West Yorkshire (1989) AC 53, 63 per Lord Keith.

A. Marsh, 'The impact of liability on public bodies: lessons from the literature', Socio-Legal Studies Association Conference 2008, Manchester, 18-20 March 2008.

See e.g. K. Oliphant, in K. Oliphant (ed.), The Liability of Public Authorities in Comparative Perspective. See Barrett v. London Borough of Enfield, (2001) 2 AC 550, 571 per Lord Slynn.

(1978) AC 728, 754. 
between policy spheres and operational spheres. ${ }^{34}$ The former is strongly linked with planning activities (such as assessing budgetary priorities), while the latter refers to the practical execution of policy decisions. According to Lord Wilberforce, when a public body is acting in the policy sphere, the courts should abstain - wholly or in part - from interfering with their activities by subjecting them to a duty of care. The more operational a power or duty is, the easier it is to superimpose on it a duty of care. This makes sense from an economic perspective and can be linked to our first (policy) and second (operational) criteria. Acts with a planning nature are more likely to be surrounded with substantial uncertainty than the execution of set tasks. For decisions in the policy sphere, policymakers need to balance various precious but conflicting interests such as order, individual liberty, personal security, care of the vulnerable and so on. ${ }^{35}$ Obviously, for such difficult exercises, opinions in society may differ strongly and thus uncertainty would loom large in the absence of (partial) immunities.

In some cases, English courts have used 'irrationality' or 'Wednesbury unreasonableness ${ }^{36}$ as a precondition of the liability of a public authority. ${ }^{37} \mathrm{~A}$ decision or action is irrational if it is so unreasonable that no reasonable public authority could have reached or done it. This is clearly in line with the third economic principle.

Not all rules of English public authority liability are in accordance with the economic precepts related to defensive behaviour. First, a breach of statutory duty causing damage can only attract liability if it can be shown that Parliament intended to protect the class of which the claimant is a member from the adversity in question and also had in mind to provide a remedy in damages if damage should result. The courts have been rather disinclined to find any intent to impose liability in damages where a public authority is the defendant. ${ }^{38}$ Obviously, this restrictive attitude goes much further than what economics would prescribe to prevent defensive behaviour. Statutory duties are often described quite precisely, and thus defensive behaviour is quite unlikely. Second, some exclusions from liability, to the extent that these provide (quasi) blanket immunities, are not sound from an economic perspective. For example, systematically denying a duty of care for the police in the investigation and suppression of crime is a bridge too far. In the current situation, a victim of a human rights violation resulting from gross negligent police behaviour can be denied

34 Note that in the case of Rowling v. Takaro Properties Ltd ((1988) AC 473, 501), Lord Keith noted that the policy-operations distinction is not 'a touchstone of liability'. In other words, it does not in itself determine whether there is a duty of care. P. Schuck, 'Suing Government: Citizen Remedies for Official Wrongs', 68 Yale University Press (1983), p. 64 . In public law, a public authority's conduct is unlawful if it is illegal, procedurally improper or irrational. The test of 'Wednesbury unreasonableness' was developed in Associated Provincial Picture Ltd v. Wednesbury Corp (1948) 1 King's Bench (KB) 223. 
a remedy based on the defensive practice argument. ${ }^{39}$ However, it is difficult to argue that police officers face substantial uncertainty from an ex ante perspective for this kind of behaviour.

\section{B. FRANCE}

To a large extent, French law on public authority liability seems to be at the opposite side of English law. France has a rather broad liability for public authorities. ${ }^{40}$ Public authorities have been found liable in diverse spheres such as those of the social services, the police, the emergency services, education, highway maintenance, regulatory activities, licensing and immigration authorities. In l'arrêt Blanco of 8 February $1873,{ }^{41}$ the Tribunal des Conflits accorded jurisdiction to the administrative courts to decide actions brought against the state 'for damages caused by the actions of persons which it employs in the public service' and pronounced a broad principle of state liability. The administrative courts gradually developed the principles of state liability, and in the process circumvented the impact of various statutory immunities. ${ }^{42}$ According to the general principle, liability will arise whenever a public body commits a fault that causes a loss. ${ }^{43}$ When the loss stems from an administrative act, any form of illegality (public law unlawfulness, substantive or procedural) constitutes fault per se ('unlawfulness equals fault'). The only acts which are considered not to be justiciable are 'actes de gouvernement'. 4

When the loss arises due to physical acts of public bodies, it will be determined whether a 'faute de service' has occurred. Neither the legislature nor the courts have given a specific definition of this concept. ${ }^{45}$ According to many academics, one has to investigate whether the standard of normal operation of the administration has been breached. A malfunctioning of the administrative machinery gives rise to a fault. ${ }^{46}$

39

by Clearing the Public Policy Fog', 22 King's Law Journal (2011), p. 27-55.

See B. Markesinis et al., Tortious Liability of Statutory Bodies: a Comparative and Economic Analysis of Five English Cases (Hart Publishing, 1999): 'It is impossible to proceed and compare specific cases before stressing how different French and English law are in their approach towards the question of administrative liability'.

41 TC 8 February 1873, Blanco, D. 1873.3.17.

42 See D. Fairgrieve and F. Lichere, 'The Liability of Public Authorities in France', in K. Oliphant (ed.), The Liability of Public Authorities in Comparative Perspective. Note that this is supplemented with various heads of liability without fault. However, these are not within the scope of this article.

These acts concern France's international relationship with other countries, the relationship between the executive and Parliament, and measures taken to protect French nationals and their property abroad.

45 See C. Gour, 'Faute de Service', in F. Gazier and R. Drago (eds), Dalloz Encyclopédie de Droit Public: Répertoire de la Responsabilité de la Puissance Publique (Dalloz, 2015), para. 116-148. Liability of Public Authorities in Comparative Perspective. 
While public bodies are liable for a 'faute de service' before the administrative courts, a public servant can be held personally liable before the ordinary civil courts if his or her conduct amounts to a 'faute personnelle'. Often the victim has the option to sue either the public authority before the administrative courts or the civil servant before the civil courts. It is not easy to distinguish between a 'faute de service' and a 'faute personnelle'. The courts take various factors into account, such as the state of mind of the official (such as corruption or personal gain), his or her behaviour (such as the use of disproportionate force), and motive (such as acts motivated by vengeance). ${ }^{47}$ If the cause of the damage lies in a personal fault of the civil servant, a claim may be made cumulatively against the public authority if there is a nexus with employment. The Conseil d'Etat recognized that there can be a dual fault ('faute de service' and 'faute personnelle') that may lead to an action against the public authority. Furthermore, the Conseil d'Etat recognizes the possibility to sue the public authority even when there is no 'faute de service' when the official's acts are 'not deprived of any link with the public service'. While a public body can bring a recursory action against the public servant who was responsible for the 'faute personnelle, such actions are rarely initiated.

At first sight, French public authority liability is very broad and seems to leave little room for immunity, for example in case of uncertain decision-making. It would seem that the economic criteria do not play a role. However, there are particular cases where the fault standard is increased to 'faute lourde' (gross negligence). This notion has been regarded as a judicial means of showing deference to the legitimate exercise of discretion by public bodies. ${ }^{48}$ Especially in the regulatory and the supervisory sphere, where uncertainty often looms large, judicial fears of second-guessing have been put to rest by the application of 'faute lourde'. Furthermore, the danger of defensive behaviour has been explicitly referred to in a conclusion of the Commissaire du Gouvernement Rivet before the French Conseil d'Etat. ${ }^{49}$ The Commissaire du Gouvernement argued that the danger of defensive practices may be an argument in favour of a higher standard of care ('faute lourde'), more particularly in order to protect the police from actions in tort. $\mathrm{He}$ held: 'In order to fulfil the difficult task of maintaining order on the streets, the police must not have their activities hindered by the threat of complicated litigation'.

Originally, 'faute lourde' was applied in numerous categories of state liability. More recently however, the administrative courts have set in motion a decline in the use of this concept ${ }^{50}$ for example in domains like medical care and the emergency services. To the extent that uncertainty regarding desirable behaviour is smaller in these spheres than in those in which 'faute lourde' is still applied, a shift to 'faute simple' can be in accordance with the criteria of our economic framework. An interesting example involves the

47

Gross negligence and recklessness can be seen as a personal fault if they are 'serious' enough. See e.g. Cass. October 21, 1997.

48

49

50

Ibid.

CE 13 March 1925, Clef, Revue du Droit Public (RDP) 1925.274,276.

R. Chapus, Droit Administratif Général, para. 1463. 
lack of sufficient warnings for leisure activities in public places. When it concerns a crowded place, 'faute simple' is used. Otherwise, the requirement is 'faute lourde'. This is economically sound and corresponds to an application of the first economic criterium. When a crowded place is involved, it is quite clear that substantial warnings, which are often not too costly, can be socially valuable. For places that are not frequented often, there can be substantial uncertainty about the productivity of investments in warnings and thus whether these funds could be better used elsewhere.

Interestingly, the standard of 'faute lourde' has also been used in a case in which depositors of a failed bank claimed that the banking regulator (la Commission Bancaire) had undertaken its supervisory duty negligently. The Commissaire du Gouvernement Seban advocated that a higher standard should be used, inter alia because the victims suffered solely 'pure economic loss', which would merit less protection by the courts. ${ }^{51}$ In economic analysis, the desirability of compensation for pure economic loss has been highly debated for a variety of reasons, one of them being that pure economic loss does not create a social loss, but only a transfer of wealth. ${ }^{52}$ Note that the introduction of the requirement of a 'faute lourde' may also make sense from the perspective of defensive behaviour. The uncertainty surrounding the decisions of banking regulators may be substantial (criterion 1); given the complexity of the tasks of banking regulators precise actions they need to take can generally not be set up in advance (criterion 2 is not applicable); and given that the financial and reputational costs of liability may be large, there may be a real risk of defensive practices. ${ }^{53}$

Finally, there are economic reasons that may justify the illegality-fault parity in French law. Ideally, fault should be the key issue, not unlawfulness. But there are practical hurdles which need to be taken into account. An example may illustrate this. Suppose a civil servant has to take a decision in 1,000 (permit) cases each year. In each case, he or she needs to check whether 10 specific regulations are complied with. It may very well be that it is economically optimal that the civil servant invests his time and effort in these cases until there will be on average 995 cases decided correctly, and 5 that are not. It may thus be the case that further investments by the civil servant are not socially desirable, even though they could still reduce his or her error rate. This will be the case when the benefits of further investments (reduced error costs) are smaller than their costs (extra time, effort and so on). So even when the civil servant behaves optimally (no fault), there may still be an unlawful decision on his part (such as on average 5 in 1,000). Now there are two possibilities: either the amount of time and effort the civil servant spends on

51 CE 30 November 2001, Kechichian, conclusions A. Seban, Les Petites Affiches, no. 28, 7 February 2002, $7,12,13$. The plenary session of the Conseil d'Etat followed this solution (Conseil d'Etat 30 November 2001, Kechichian, AJDA 2002.136).

52 See on the desirability of the compensation of pure economic loss, J. De Mot, 'Pure Economic Loss', in M. Faure (ed.), Tort Law and Economics (Edward Elgar, 2009).

53 On the influence of large financial and reputational costs generally, see J. De Mot and M. Faure, 'Public Authority Liability and The Chilling Effect', 22 Tort Law Review (2014), p. 126-128. 
his tasks are verifiable for the courts, or they are not. In the former case, the courts can simply check whether the civil servant acted negligently or not. Even though the conduct may have been unlawful, it could very well be that he did not commit a fault. However, in reality the time and effort spent by the civil servant will generally be unverifiable. In that case, unlawfulness should generally lead to the conclusion that there has been a fault. The alternative would be never to hold the civil servant liable because he could always claim that the unlawfulness was a mere accident (occurring 5 in 1,000 times even when he behaves without fault). ${ }^{54}$ In other words, when behaviour is not verifiable (at all), it may be wise to assimilate unlawfulness with fault, to preserve incentives. Expressed in another way, this comes down to creating a pocket of strict liability into the negligence rule.

\section{GERMANY}

With respect to public liability in Germany, the main legal basis can be found in $\$ 839$ of the Civil Code (Bürgerliches Gesetzbuch; BGB) in conjunction with Article 34 Basic Law (Grundgesetz; GG). ${ }^{55}$ The liability of the individual civil servant and of the public authority where the civil servant works are strictly coupled. $\$ 839$ BGB states:

If an official wilfully or negligently commits a breach of official duty incumbent upon him towards a third party, he shall compensate the third party for any damage arising therefrom. If only negligence is imputable to the official, he may be held liable only if the injured party is unable to obtain compensation otherwise.

Article 34 GG states:

If any person, in the exercise of a public office entrusted to him, violates his official obligations to a third party, liability shall rest in principle on the State or the public body which employs him. In the event of wilful or grossly negligent conduct, the right of recourse shall be reserved.

The personal liability of the servant is thus substituted by the liability of the state: however the state may claim redress against the servant if the latter acted with intent or gross negligence.

German law makes a distinction between decisions involving discretion and 'bound decisions'. Discretion can comprise the choice whether to act or which decision to take ${ }^{56}$ (at least when the requirements of the statute authorizing the exercise of discretion are fulfilled). If the official acts within the ambit of the discretion conferred upon him, there shall be no liability. Note however that German courts do not identify an area of

54 A more refined alternative could be to hold the civil servant liable in case of repeated errors.

55 See U. Magnus, 'The liability of public authorities in Germany', in K. Oliphant (ed.), The Liability of Public Authorities in Comparative Perspective.

56 H. Maurer, Allgemeines Verwaltungsrecht (11 ${ }^{\text {th }}$ edition, C.H. Beck, 1997), p. 121-122. 
discretion which is beyond any judicial control from the outset. Although the courts are not allowed to substitute their decision for the one of the public body, they can review specific errors of the public body in the exercise of its discretion. For liability to arise, it is sufficient that the official applied his discretion incorrectly, even if it did not amount to evident abuse. ${ }^{57}$ This seems to be in line with the first two economic principles described above. For decisions involving discretion, and thus substantial uncertainty, there may be immunity; for other decisions involving set tasks and thus no or little uncertainty, there is no immunity. Moreover, the immunity does not go further than necessary and thus prevents defensive behaviour while at the same time preserving incentives for acting carefully. Obviously there is no immunity if no reasonable person could come to the decision made by the public authority (criterion 3).

Article 34 GG is seen as a way of protecting the individual official from the risk of personal liability which could otherwise lead to a defensive approach. This would also indirectly benefit public authorities because their functioning depends on the performance of their officials. ${ }^{58}$ Interestingly, the purpose of the subsidiarity clause in $\$ 839$ (I)(2) BGB, which was created almost 50 years before Article 34 GG, was also to maintain the decisiveness of public officials. ${ }^{59}$ According to the subsidiarity clause, public authority liability comes subsidiary to the liability of other liable persons. If redress is possible from those persons, they will have to bear the full loss and public authority liability is excluded. For example, when an explosion of a fireworks factory takes place, victims may want to hold the public authority liable for either having wrongly issued the licence ${ }^{60}$ or for insufficient supervision of the imposed conditions. However, the primary tortfeasor will often be the operator of the fireworks facility. The fact that in Germany victims first have to address the potentially liable operator could substantially restrict public authority liability and therefore help to mitigate defensive behaviour in some cases. However, given that the public official is already protected by Article $34 \mathrm{GG}$, the subsidiarity clause no longer seems necessary. Moreover, the clause may reduce the public authority's incentive to take adequate care in some circumstances. Suppose the public authority needs to supervise whether a fireworks company stores its fireworks appropriately and that the supervisor knows there is a chance that the company will, due to a lack of expertise, not store the fireworks carefully. If the company has sufficient financial means to pay damages, ${ }^{61}$ the supervisor knows that the public authority will not be held liable if harm materializes because of the subsidiary nature of its liability.

BGHZ 74, 144, 156; 75, 120, 124; O. Palandt and H. Heinrichs, $B G B\left(58^{\text {th }}\right.$ edition, C.H. Beck, 1999), $\$ 839$, margin note 36 .

K. Windthorst and H. Sproll, Staatshaftungsrecht (1 $1^{\text {st }}$ edition, C.H. Beck, 1994), p. 59-60.

B. Mugdan (ed.), Die gesamten Materialien zum Bürgerlichen Gesetzbuch für das Deutsche Reich (Deckers Verlag, 1899), p. 1385-1403; F. Ossenbühl, Staatshaftungsrecht (5 ${ }^{\text {th }}$ edition, C.H. Beck, 1998), p. 79.

E.g. that in that particular residential area such a factory would not be allowed or that insufficiently strict conditions were imposed.

In reality, this may seldom be the case. 
Consequently the incentive to monitor the primary tortfeasor properly is reduced. In 1981, the legislator tried to abolish the subsidiarity clause, but the act was later declared unconstitutional by the Federal Constitutional Court because of lack of legislative competence of the Federation. ${ }^{62}$

\section{\$4. CONCLUSION}

The basic rules of public authority liability are compliant to a considerable extent in France and Germany, and to a lesser extent in England, with the economic principles underlying defensive behaviour. Immunity is mainly granted when there is considerable uncertainty in decision-making and is often not granted when the law specifies the precise action to be taken by the public authority or when no reasonable person could come to the decision made by the public authority. With respect to England, the distinction between policy spheres and operational spheres and the concept of 'Wednesbury unreasonableness' fit well into the economic framework. Regarding France, the standard of faute lourde, when correctly applied, can provide immunity for decisions surrounded with substantial uncertainty, which is economically justified. Similarly, the German distinction between decisions involving discretion and 'bound decisions' makes economic sense. Of course, each jurisdiction has its own peculiar rules which makes it deviate from economic optimality. For example, the German rule of subsidiarity may reduce the public authority's incentive to take adequate care in some circumstances. And in England, the strict rules regarding the breach of statutory duty and the categorical exclusion of some liabilities go much further than necessary to prevent defensive behaviour.

62 H. Papier, 'Article 34', in T. Maunz and G. Dürig (eds.), Komm zGG (C.H. Beck, 1998), margin note 89-96. 